\title{
Serum Electrolyte Imbalances in Head Injury Patients: An Institutional Analysis
}

\author{
Dr. Anand Kumar Jha ${ }^{1}$, Dr. Minakshi Kumari ${ }^{2}$, Dr. Saurav Kumar ${ }^{3}$, Dr. Peeyus Tomar ${ }^{4}$, \\ Dr. Anand Prakash", Dr. (Prof.) Anil Kumar \\ ${ }^{1}$ Resident, Department of Neurosurgery, RIMS Ranchi, Jharkhand \\ ${ }^{2,3,4,5}$ Resident, Department of Biochemistry, RIMS Ranchi, Jharkhand
}

${ }^{3}$ Professor \&Head Department of Neurosurgery, RIMS Ranchi, Jharkhand

\begin{abstract}
Traumatic brain injury is an important cause of mortality and morbidity in all age group of patients. Electrolyte imbalance is common in patients with traumatic brain injury patients. Aim of this study is to estimate the prevalence of electrolyte disturbance in head injury patients. This is a prospective study carried out at RIMS, Ranchi, Jharkhand. Total 210 patients included in this study during 9 months period. We measured the serum level of sodium, potassium, and calcium and GCS score and CT reports of every patient daily and data collected in TBI proforma and analysed for the results. Abnormal sodium level was found in $39.03 \%$ patients, abnormal potassium level was found in $31.80 \%$ patients, and abnormal calcium level was found in $20 \%$ patients. Hyponatremia, hypokalemia and hypocalcemia are more common than hypernatremia, hyperkalemia and hypercalcemia in head injury patients. Patients with severe head injury had abnormal sodium and potassium level as compared to mild and moderate head injury. Electrolyte disturbances should be measured at regular interval and meticulously treated in traumatic brain injury patients to increase the survival of patients.
\end{abstract}

Keywords: Traumatic brain injury (TBI), hyponatremia, hypokalemia, hypocalcemia, Glasgow coma scale (GCS) score

\section{Introduction}

Traumatic brain injury (TBI) is a leading cause of morbidity and mortality and socioeconomic losses in developing countries like India. About $50-60 \%$ of the road traffic accident patients are hospitalised for traumatic brain injury (1). Patients of TBI have high risk of electrolyte derangements, it will affect management and outcome of patients. It is likely due to use of diuretics, fluids, syndrome of inappropriate antidiuretic hormone secretion and cerebral salt wasting. Hyponatremia is a common electrolyte disturbance following TBI (2). Rapid correction of hyponatremia may lead to neurological symptoms $(3,4)$. Potassium is present in high concentration intracellular as compare to extracellular, small change in potassium can severely affect nerve conduction, muscle contraction and rhythm of heart (5). Serum calcium is also an important electrolyte abnormality in TBI patients associated with muscle spasm, cardiac arrhythmia, heart failure and neuromuscular irritability (6). Both hypocalcaemia and hypercalcaemia can occur. TBI can lead to electrolyte disturbances which may be critical for survival of patients. There are some different causes and among them most common is SIADH (7). Other causes are use of diuretics like mannitol and furosemide, cerebral salt wasting syndrome $(8,9)$.Detection at appropriate time and adequate management improves neurological outcome (10). This study was designed to know the serum derangements of different electrolytes in patients of head injury and to analyse its effect on treatment and outcome of the patients.

\section{Materials and Methods}

The patients of TBI who were admitted to neurosurgery department of RIMS, Ranchi, Jharkhand for a period of nine months from January 2017 to September 2017 were taken for the study. It was a type of prospective study after the institutional ethical approval and written informed consent. Patients of all age groups with TBI were taken for this study. The patients not willing to take part in study, patients with end organ failure, diabetes mellitus, diabetes insipidus and patients with chronic diuretic therapy were excluded from the study.

At the time of admission the level of consciousness was assessed with GCS score. CT skull of head was also done at the time of admission to assess the types of head injury, and the blood samples were sent to Biochemistry department for serum sodium, serum potassium, and serum calcium at the time of admission and after 24 hours of admission following resuscitation. The estimation of serum sodium and serum potassium was done in an ecolyte machine by ion selective electrode method. Normal serum sodium was considered between $135-145 \mathrm{mEq} / \mathrm{L}$, normal serum potassium level was between $3.5-5 \mathrm{mEq} / \mathrm{L}$ and normal reference range for calcium was considered between 9-10.8 $\mathrm{mg} / \mathrm{dl}$. The variables taken for the study were age, sex, cause,GCS, serum level of sodium, potassium, and serum calcium of the patients. All data were noted in proforma and were entered in excel sheet.

\section{Results}

There were total of 210 patients were included in our study and were managed in our department of neurosurgery. 157 $(74.76 \%)$ patients were male and $53(25.23 \%)$ were female and male to female ratio of patients was $3: 1.58(27.61 \%)$ patients belong to age less than 18 years, $122(58.09 \%)$ patients were from age 20 to 50 years and 30 (14.28\%) patients belong to age more the fifty years (Table $\mathbf{1}$ ). 


\section{International Journal of Science and Research (IJSR) \\ ISSN (Online): 2319-7064}

Index Copernicus Value (2016): 79.57 | Impact Factor (2015): 6.391

Most common mechanism of TBI in our study were due to road traffic accident $(56.67 \%)$, followed by fall from height which contributes $56(26.67 \%)$, others like assault contributes $31(14.76 \%)$ and sports related injuries in 4 (1.90\%) \{Table 2\}. Out of 210 patients 93 (44.28\%) patients had mild TBI, 69 (32.85\%) patients had moderate head injuries and $48(22.85 \%)$ patients had severe head injuries (Table 4). Most common CT scan finding in our study were fracture of skull $44(21 \%)$ patients, followed by extradural hematoma $43(20.47 \%)$ patients, subdural hematoma $39(18.57 \%)$ patients, subarachnoid hemorrhage $31(14.76 \%)$ patients, diffuse axonal injuries 30 (14.28\%), and $23(10.95 \%)$ patients had contusions (Table 3).

Among 210 patients $128(60.95 \%)$ patients normal serum sodium level, hyponatremia seen in $53(25.23 \%)$ patients and $29(13.80 \%)$ had hypernatremia. Hypokalemia observed in $44(20.95 \%)$ patients, hyperkalemia in $23(10.95)$ patients and $143(68.09 \%)$ patients had normal potassium level. Hypocalcaemia were present in 31 (14.76\%) patients, hypercalcaemia in $11(5.23 \%)$ patients and in $168(80 \%)$ patients no change in serum calcium level (Table 5). Out of 48 severe injured patients $46(95.83 \%)$ had abnormal sodium level, $33(68.75 \%)$ patients had abnormal potassium level and $19(39.58 \%)$ had abnormal calcium level (Table 6).

Table 1: Demographic characteristics

\begin{tabular}{|c|c|c|c|}
\hline \multicolumn{2}{|c|}{} & Number of patients & Percentage of patients \\
\hline \multirow{3}{*}{ Age } & $<18$ years & 58 & 27.61 \\
\cline { 2 - 4 } & $18-50$ years & 122 & 58.09 \\
\cline { 2 - 4 } & $>50$ years & 30 & 14.28 \\
\hline \multirow{2}{*}{ Sex } & Male & 157 & 74.76 \\
\cline { 2 - 4 } & female & 53 & 25.23 \\
\hline
\end{tabular}

Table 2: Mode of traumatic brain injury

\begin{tabular}{|l|l|l|} 
Mechanism of injury & Number of patients & Percentage of patients \\
\hline
\end{tabular}

\begin{tabular}{|c|c|c|}
\hline RTA & 119 & 56.67 \\
\hline Fall from height & 56 & 26.67 \\
\hline Assault & 31 & 14.76 \\
\hline Sports related injury & 4 & 1.90 \\
\hline
\end{tabular}

Table 3: CT scan findings

\begin{tabular}{|c|c|c|}
\hline NCCT finding & Number of patients & Percentage of subject \\
\hline Fracture & 44 & 21 \\
\hline EDH & 43 & 20.47 \\
\hline SDH & 39 & 18.57 \\
\hline SAH & 31 & 14.76 \\
\hline DAI & 30 & 14.28 \\
\hline Contusion & 23 & 10.95 \\
\hline
\end{tabular}

Table 4: Severity of head injury

\begin{tabular}{|c|c|c|}
\hline Severity of head injury & No. of patients & Percentage \\
\hline Mild (GCS14-15) & 93 & 44.28 \\
\hline Moderate (GCS 9-13) & 69 & 32.85 \\
\hline Severe (GCS <9) & 48 & 22.85 \\
\hline
\end{tabular}

Table 5: Incidence of electrolyte imbalance

\begin{tabular}{|l|l|l|}
\hline $\begin{array}{l}\text { Electrolyte } \\
\text { imbalance }\end{array}$ & $\begin{array}{l}\text { No of } \\
\text { cases }\end{array}$ & Percentage \\
\hline Hyponatremia & 53 & 25.23 \\
\hline Hypernatremia & 29 & 13.80 \\
\hline Hypokalemia & 44 & 20.95 \\
\hline Hyperkalemia & 23 & 10.95 \\
\hline Hypocalcaemia & 31 & 14.76 \\
\hline hypercalcaemia & 11 & 5.23 \\
\hline
\end{tabular}

\section{Volume 6 Issue 12, December 2017} www.ijsr.net

Licensed Under Creative Commons Attribution CC BY
Table 6: Relationship of sodium, potassium and calcium abnormalities with severity of head injury

\begin{tabular}{|c|c|c|c|}
\hline $\begin{array}{c}\text { Electrolyte } \\
\text { imbalance }\end{array}$ & $\begin{array}{c}\text { Mild } \\
\text { TBI }\end{array}$ & $\begin{array}{c}\text { Moderate } \\
\text { TBI }\end{array}$ & $\begin{array}{c}\text { Severe } \\
\text { TBI }\end{array}$ \\
\hline Hyponatraemia & 9 & 17 & 27 \\
\hline Hypernatraemia & 3 & 7 & 19 \\
\hline Hypokalaemia & 9 & 13 & 22 \\
\hline Hyperkalaemia & 7 & 5 & 11 \\
\hline hypocalcaemia & 5 & 9 & 17 \\
\hline hypercalcaemia & 6 & 3 & 2 \\
\hline
\end{tabular}

\section{Discussion}

Head injuries are common cause of morbidity and mortality. Electrolyte derangements are common in patients with TBI (12).The head injuries are common in males and in the younger people because of more involvement of male young in outside activities. RTA were the most common mechanism of head injury (56.53\%), followed by fall from height $(26.7 \%)$. Mild head injuries are commoner than moderate and severe head injuries, in our study it contributes $44.3 \%$ followed by moderate head injuries (32.85\%).

Most common electrolyte imbalances are serum sodium and potassium levels following a head injury. Pharmacological therapy like diuretics and resuscitation by fluid are mainly responsible for these electrolyte derangements (13). The incidence of hyponatraemia is $25.23 \%$ which was high as compare to study done by Nobuhiro Moro et al (14). Hyponatremia may develop as a result of SIADH and cerebral salt wasting (CSW) syndrome in TBI patients, brain natriuretic peptide may also responsible for hyponatraemia (15). Incidence of hypernatraemia was $13.80 \%$. The cause for hypernatremia could be diabetes insipidus, hypothalamic pituitary dysfunction and use of mannitol, but in severe head injury patients the incidence $65.51 \%$ which was high as compared to study done by Das et al $(63.15 \%)$ Rochdi et al $(30.23 \%)$,Umberto Maggiore et al $(51.5 \%)$. Potassium was the second most common electrolyte derangements following serum sodium levels. The incidence of hypokalaemia was $20.95 \%$ which was less in comparison to study of Beal AL et al $(27.5 \%)$ but higher in compared to study done by Das et al $(12.35 \%)$ (16) but in severe head injury patients the incidence of hypokalemia was $50 \%$. Patients with severe head injury are at high risk of hypokalemia, it might be due to an increase in urinary loss caused by brain trauma. Patients with severe TBI are at risk of polyuresis due to syndrome of inappropriate antidiuretic hormone and cerebral salt wasting syndrome. In our study high serum potassium level was found in $10.95 \%$ of patients which was lower than incidence of hypokalemia (20.95\%). These changes might be due to the high catecholamine secretions following severe head trauma, with resultant beta2- adrenergic stimulation of the Na-K pump (17). In our study we had more patients with hypocalcaemia $(14.76 \%)$ than hypercalcemia $(5.23 \%)$. Serum calcium changes leads to a variety of clinical manifestations like tetany, convulsions and muscle spasm (18). Accumulation of intracellular calcium render an abnormal responses of neurons to stimulation in severe TBI are responsible for these features (19). 


\section{International Journal of Science and Research (IJSR) \\ ISSN (Online): 2319-7064}

Index Copernicus Value (2016): 79.57 | Impact Factor (2015): 6.391

A shift of electrolytes from extracellular compartment to intracellular compartment and electrolyte loss through polyuresis in traumatic brain injury plays a role in electrolyte imbalances. The levels of sodium, potassium and calcium should be measured routinely in all patients with head injury and especially in patients with severe head injury because imbalances in level of these electrolytes are likely to remain undetected for a longer time.

\section{Conclusion}

Patients with traumatic brain injury are often accompanied by electrolyte abnormalities especially the hyponatremia and hypokalemia are common. Polyuresis due to SIADH, CSW and uses of osmotic diuretics like mannitol, hypernatremia due to diabetes insipidus may occur but lower in incidence than hypernatremia. All types of electrolyte abnormalities are seen more in severe type of head injury patients. Therefore the electrolyte imbalance in traumatic brain injury patients is an important factor for prognosis, so early diagnosis and adequate management of elelctrolyte abnormalities are essential to decrease the mortality and morbidity.

\section{References}

[1] (2005) Burden of disease in India. National Commission on Macroeconomics and Health background papers, Ministry of Health \& Family Welfare, New Delhi, India.

[2] Lath R (2005). Hyponatremia in neurological diseases in ICU. Indian J, Crit. Care Med. 9:47-51

[3] Isotani E, Suzuki R, Tomita K (1994). Alterations in plasma concentrations of natriuretic peptides and antidiuretic hor-mone after subarachnoid hemorrhage. Stroke. 25:2198-203

[4] Lohani S, Devkota UP (2011). Hyponatremia in patients with traumatic brain injury: etiology, incidence, and severity correlation.WorldNeurosurg. 76 (3-4):355-60.

[5] Goldman, M.J. (1973). Principles of Clinical Electrocardiography 8th ed. Los Altos, California: LANGE medical Publications. p. 293

[6] Munro Peacock. Calcium Metabolism in Health and Disease. CJASN January 2010; 5 (Suppl 1): S23-S30

[7] Gribkov AV, Fraerman AP, Salalykin VI, Salmin AA, Sidorkin VG (1992) Regulation of the water-electrolyte balance during neurosurgical operations with balanced anesthesia using sodium oxybutyrate. Anesteziol Reanimatol (1): 28-31.

[8] Gaab M, Knoblich OE, Schupp J, Herrmann F, Fuhrmeister U, et al. (1979) Effect of furosemide on acute severe experimental cerebral edema. J Neurol 220 (3): 185-197.

[9] Askar A, Tarif N (2007) Cerebral salt wasting in a patient with head trauma: management with saline hydration and fludrocortisone. Saudi J Kidney Dis Transpl 18 (1): 95-99.

[10] Ishizaki T, Momota H, Kuwahara K, Tanooka A, Morimoto S. A. case of symptomatic traumatic cerebral vasospasm associated with hyponatremia. No Shinkei Geka 1999 Nov; 27: 1031-6. [Articlein Japanese].
[11] Rhoney DH, Parker D (2006) Considerations in fluids andn electrolytes after traumatic brain injury. Nutr Clin Pract 21 (5): 462- 478.

[12] Marik PE, Bedigian MK (1996) Refeeding hypophosphatemia in critically ill patients in an intensive care unit: A prospective study. Arch Surg 131 (10): 1043-1047.

[13] Guggiari M, Georgescu H (1994) The injured brain. Basis for hydro electrolytic and hemodynamic resuscitation. Ann Fr Anesth Reanim 13 (1): 98-104.

[14] Moro N, Katayama Y, Igarashi T, et al. Hyponatremia in patients with traumatic brain injury: incidence, mechanism and response to sodium supplementation or retention therapy with hydrocortisone. Surgical Neurology 2007;68 (4):387 93.

[15] Richards AM, Nicholls MG, Espiner EA (1985). Effects of alfa-human atrial natriuretic peptide in essential hypertension.Hypertension.7:812-817

[16]Das SK, Gouda PK, Sahoo N, et al. Serum sodium and potassium profile in adult head injury patients and its effect on final outcome. J. Evolution Med. Dent. Sci. 2017;6 (31):2528-2532, DOI: 10.14260/Jemds/2017/54

[17] Pomeranz S, Constantini S, Rappaport ZH (1989) Hypokalaemia in severe head trauma. Acta Neurochir (Wien) 97 (1-2): 62-66.

[18] Kogan OG, Kaishibaev SK (1961) A case of tetany developing after brain injury. Zdravookhranenie Kazakhstana 21 (10): 68-70.

[19] Gurkoff GG, Shahlaie K, Lyeth BG (2012) In vitro mechanical strain trauma alters neuronal calcium responses: Implications for posttraumatic epilepsy. Epilepsia 53 (Suppl 1): 53-60. 